\title{
The International Economic Association
}

A non-profit organization with purely scientific aims, the International Economic Association (IEA) was founded in 1950. It is a federation of some sixty national economic associations in all parts of the world. Its basic purpose is the development of economics as an intellectual discipline, recognizing a diversity of problems, systems and values in the world and taking note of methodological diversities.

The IEA has, since its creation, sought to fulfil that purpose by promoting mutual understanding among economists through the organization of scientific meetings and common research programmes, and by means of publications on problems of fundamental as well as of current importance. Deriving from its long concern to assure professional contacts between East and West and North and South, the IEA pays special attention to issues of economics in systemic transition and in the course of development. During its more than forty years of existence, it has organized some hundred round-table conferences for specialists on topics ranging from fundamental theories to methods and tools of analysis and major problems of the present-day world. Participation in round tables is at the invitation of a specialist programme committee, but eleven triennial World Congresses have regularly attracted the participation of individual economists from all over the world.

The Association is governed by a Council, composed of representatives of all member associations, and by a fifteen-member Executive Committee which is elected by the Council. The Executive Committee (1995-98) at the time of the San José Conference was:

President:

Vice-President:

Treasurer:

Past President:

Other Members:
Professor Jacques Drèze

Professor Anne Krueger, USA

Professor Erich Streissler, Austria

Professor Michael Bruno, Israel

Professor Anthony B. Atkinson, UK

Professor Vittorio Corbo, Chile

Professor Karel Dyba, Czech Republic

Professor Jean-Michel Grandmont, France

Professor Yujiro Hayami, Japan 
Advisers:

Professor Seppo Honkapohja, Finland

Professor Valeri Makarov, Russia

Professor Luigi Pasinetti, Italy

Professor Hans Werner Sinn, Germany

Professor Rehman Sobhan, Bangladesh

Professor Alan D. Woodland, Australia

Professor Kenneth J. Arrow, USA

Academician Oleg T. Bogomolov, Russia

Professor Mustapha Nabli, Tunisia

Professor Amartya Sen, India

Professor Stefano Zamagni, Italy

Secretary-General:

Professor Jean-Paul Fitoussi, France

General Editor:

Professor Michael Kaser, UK

Sir Austin Robinson was an active Adviser on the publication of IEA conference proceedings from 1954 until his final short illness in 1993.

The Association has also been fortunate in having secured many outstanding economists to serve as President:

Gottfried Haberler (1950-53), Howard S. Ellis (1953-56), Erik Lindahl (1956-59), E. A. G. Robinson (1959-62) G. Ugo Papi (1962-65), Paul A. Samuelson (1965-68), Erik Lundberg (1968-71), Fritz Machlup (1971-74), Edmond Malinvaud (1974-77), Shigeto Tsuru (1977-80), Victor L. Urquidi (1980-83), Kenneth J. Arrow (1983-86), Amartya Sen (1986-89), Anthony B. Atkinson (1989-92), and Michael Bruno (1992-95).

The activities of the Association are mainly funded from the subscriptions of members and grants from a number of organizations, including continuing support from UNESCO, through the International Social Science Council in the preparation of the project for the conference under contract CAR 101-3, 1996-. 


\section{Acknowledgements}

The San José Conference and the published proceedings depended crucially on the individuals and organizations who lend us their unconditional support. We want to thank all of them for the intellectual stimulus, and financial resources as well as organizational and editorial assistance. Above all, we are very grateful to our local organizing committee under the leadership of Juan Rafael Vargas and Vilma Calvo Castillo of the University of Costa Rica, for providing a stimulating and exciting conference atmosphere in Costa Rica.

We also wish to express our gratitude to:

José Maria Figueres Olsen, President of Costa Rica; Rebeca Grynspan Mayufis, Second Vice-President of Costa Rica; Antonio Alvarez Desanti, President of the Asamblea Legislativa of Costa Rica; Leonardo Garnier Rímolo, Minister of Planning and Economic Policies; Adrián Rodriguez Vargas, Assessor to the Ministry of Planning and Economic Policies; Anabelle Ulate Quirós, Director of the Institute of Economics, University of Costa Rica; and Raul Weissleder, National Bank of Costa Rica.

Furthermore, we would like to thank:

The Scientific Committee consisting of Rudiger Dornbusch, JeanPaul Fitoussi, Martin Paldam and Silvio Borner; Gert Tinggaard Svendsen, Aarhus Business School, Denmark; Markus Kobler, Christian Winiker, Carsten Hefeker and Sylvette Fiechter; University of Basle, Switzerland; Maureen Hadfield, IEA editorial board.

Financial support was provided generously by Swiss, Danish and German private and public foundations, as well as by private firms and we are particularly grateful to:

The Foundation Aarhus University, Research, Aarhus, Denmark; Avina Stiftung, Hurden, Switzerland; the Danish Ministry of Foreign Affairs; DEZA (Direktion für Entwicklung und Zusammenarbeit), Berne, Switzerland; and FAG (Freiwillige Akademische Gesellschaft), Basle, Switzerland.

Lastly, we thank the International Social Science Council under whose auspices the publication programme is carried out and UNESCO for continuing financial support. 


\section{List of Contributors}

Professor Joshua Aizenman, Dartmouth College, Hanover, USA Professor M. Shahid Alam, Northeastern University, Boston, USA Professor Robert H. Bates, Harvard University, Cambridge, USA Professor Peter Bernholz, University of Basle, Basle, Switzerland Professor Silvio Borner, University of Basle, Basle, Switzerland Professor Vani K. Borooah, University of Ulster, Northern Ireland, UK Professor Aymo Brunetti, University of Basle, Switzerland and Universität des Saarlandes, Germany

Professor Vittorio Corbo, Universidad Católica de Chile, Santiago, Chile

Professor Rudiger Dornbusch, Massachusetts Institute of Technology, Cambridge, USA

Professor Bruno S. Frey, University of Zurich, Switzerland

Dr Michael Gavin, Inter-American Development Bank, Washington, DC, USA

Professor Ricardo Hausmann, Inter-American Development Bank, Washington, DC, USA

Dr Dieter Kattermann, GTZ Deutsche Gesellschaft für Technische Zusammenarbeit, Eschborn, Germany

Dr Philip Keefer, The World Bank, Washington, DC, USA

Dr Tony Killick, Overseas Development Institute, London, UK

Professor Mwangi S. Kimenyi, University of Connecticut, Storrs, USA

Professor Robert Klitgaard, RAND Graduate School, Santa Monica, USA

Dr Stephen Knack, American University, University of Maryland, USA Professor John Mukum Mbaku, Weber State University, Ogden, USA Professor Martin C. McGuire, University of California-Irvine, USA Professor Mancur Olson Jr, University of Maryland, USA

Professor Martin Paldam, University of Aarhus, Denmark

Dr Guy P. Pfeffermann, International Finance Corporation, The World Bank, Washington, DC, USA

Dr Geoffrey Shepherd, The World Bank, Washington, DC, USA

Dr Beatrice Weder, International Monetary Fund, Washington, DC, USA

Professor Ronald Wintrobe, University of Western Ontario, London, Canada 


\section{Abbreviations and Acronyms}

ADEM undisturbed age of democracy

ASF Airport Security Force

BERI Business Environmental Risk Intelligence

BMZ German Federal Ministry for Economic Cooperation and Development

BWIs Bretton Woods Institutions

CB capacity building

CIA Central Intelligence Agency

CWD capitalist welfare states and democracies

DA direct action

DAC Development Assistance Committee

DC developed country

EBA extreme bound analysis

EP export promotion (model)

FCC former communist countries

FDI foreign direct investment

FIA Federal Investigation Agency

FINV fixed investment

FOCJ Functions overlapping competing jurisdictions

GGDP growth of gross domestic product (\%)

GTZ German Agency for Technical Cooperation

ICRG International Country Risk Guide

ID institutional development

IDB Inter-American Development Bank

IMF International Monetary Fund

IRA Irish Republican Army

ISI import substitution industrialization (model)

KDA Karachi Development Authority

KESC Karachi Electric Supply Corporation

KMC Karachi Municipal Corporation

KPT Karachi Port Trust

KRTC Karachi Road Transport Corporation

LDC less developed countries

LG local governments

NatCAP National Technical Cooperation Assessment and Programme

NBER National Bureau of Economic Research (USA) 
NIC newly industrializing countries

NIE new institutional economics

NPE new political economy

OECD Organization for Economic Cooperation and Development

PAYE pay-as-you-earn

PRI Partido Revolucionario Institucional (Mexican political party)

PT political transition

RR resource rich

SEF Social Emergency Fund

TC technical cooperation

TEXP total government expenditure as percentage of GDP

TTWA travel to work area

UN United Nations

UNDP United Nations Development Programme

VP voting popularity 


\section{Preface}

The Round-table Conference on 'The Political Dimension of Economic Growth', held under the auspices of the International Economic Association, took place in San José, Costa Rica between 31 March and 3 April 1996. It was designed to explore new trends in growth economics and the widely divergent economic performance of developing countries in the light of their political systems and institutions. Three people were responsible for the success of the conference: Juan Rafael Vargas, who dealt with all local arrangements in a Latin American setting; Martin Paldam, who took over leadership of the editing process; and Silvio Borner, who had the original idea for the conference and promoted it assiduously.

In planning the Conference and this book, care has been taken to choose authors who have demonstrated their sensitivity to the institutional dimension of the growth process. The value of this volume lies not so much in new ideas, but in bringing together various fruitful approaches to the institutional analysis of growth. It is up to the reader to decide to what degree a common ground has been achieved without recourse to either an imperialistic theoretical or ideological perspective.

This book comprises papers presented at the Conference, and is arranged in six sections, as follows:

1 The State and Development

2 Volatility, Uncertainty, Institutional Instability and Growth

3 Rent-Seeking and Corruption

4 Case Studies: Policies, Countries and International Organizations

5 Constitutional and Administrative Reform

6 Comments 



\title{
Introduction: Politics and Growth - What Are the Crucial Issues?
}

\author{
Silvio Borner
}

\section{DO DIFFERENCES IN GROWTH RATES MATTER?}

New theoretical trends in growth economics and the enormous performance differences in developing countries seemed an appropriate theme for a conference in Costa Rica. To answer the question, let us start by comparing two countries in different continents, Bolivia and Malaysia, for example. Although these two countries lie far apart, they share similar characteristics. Both have rich natural resources and multicultural populations, and in 1965 they had similar production structures. The share of agriculture in Bolivia's gross domestic product (GDP) was 23 per cent, in Malaysia it was 28 per cent; Bolivian industry had a 31 per cent share of GDP, Malaysian industry had 25 per cent, although the share of manufacturing was a little higher in Bolivia (15 per cent) than in Malaysia (9 per cent). Their levels of per capita gross national product (GNP) were also similar: US\$870 in Malaysia and US\$745 in Bolivia.

Were there any clues in 1965 about the developmental prospects of these two countries? Could we have forecast how dissimilar their economic progress would be over the following thirty years? Most of us would have predicted a similar pattern of development, but in the course of one generation Malaysia tripled its per capita GNP to US\$2320 while, by 1990, Bolivia's had shrunk to just US\$630.

This example is not unique. Since the 1960s almost all Latin American countries have displayed poor economic performance, while many SouthEast Asian countries have astonished the world with performances that have exceeded all expectation. Figure 1 shows the per capita GNP of a selection of four South-East Asian and six Latin American countries in 1965 and 1990. It can be seen that per capita GNP increased substantially 


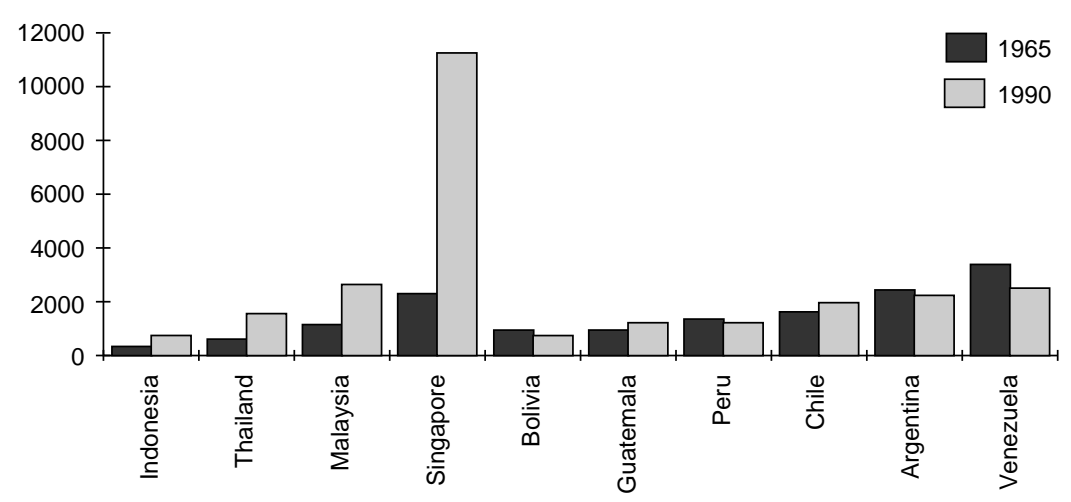

Figure 1 Levels of per capita GNP, 1965 and 1990

in all four South-East Asian countries, while in the Latin American countries it either stagnated or fell. Singapore's success illustrates the power of compound interest: an average annual per capita growth of 6.5 per cent does not sound spectacular, but over a period of twentyfive years this translates into a five-fold increase in per capita GNP.

In Figure 2, the difference in performance between the South-East Asian and Latin American countries stands out even more starkly. Compare this with the picture that would have resulted if all ten countries had achieved Singapore's 6.5 per cent annual growth rate (Figure 3). Venezuela, whose performance since 1965 has been the poorest of the sample chosen, would instead have led in terms of per capita GNP. Conversely, Figure 4 shows what would have happened if all ten countries had copied Venezuela's performance. In the best-case scenario (Figure 3 ), the sample's average per capita GNP would have been US\$6368; and in the worst-case scenario it would have been just US\$1104. Within the span of a single generation the actual differences in the growth rates of per capita GNP have translated into enormous differences in the expectations and outlook of millions of people.

\section{WHAT DO WE KNOW ABOUT THESE DIFFERENCES?}

Growth theory, as shown in Figure 5, can be subdivided into two branches: 


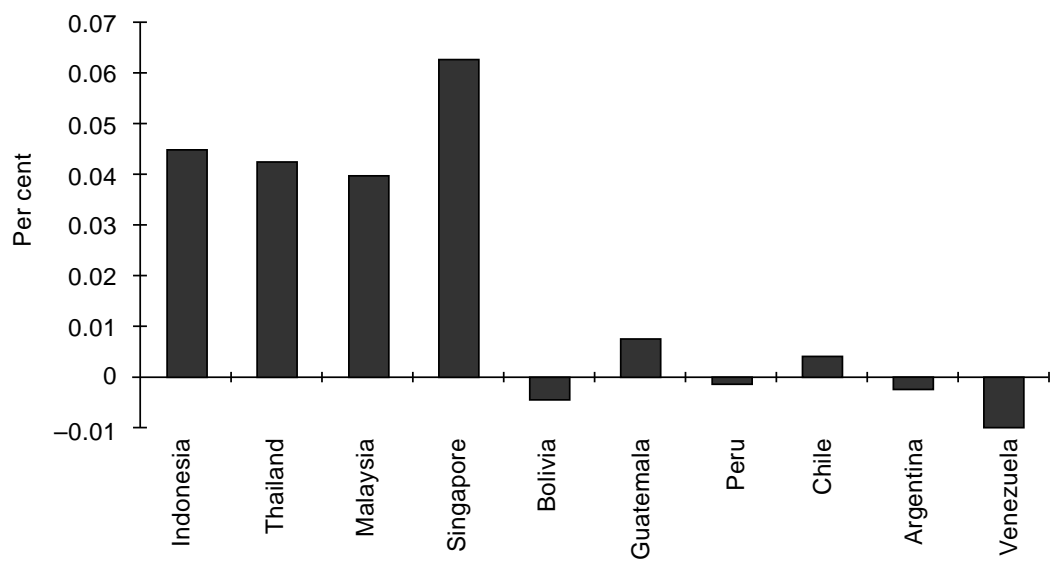

Figure 2 Average annual growth rates of per capita GNP, 1965-90

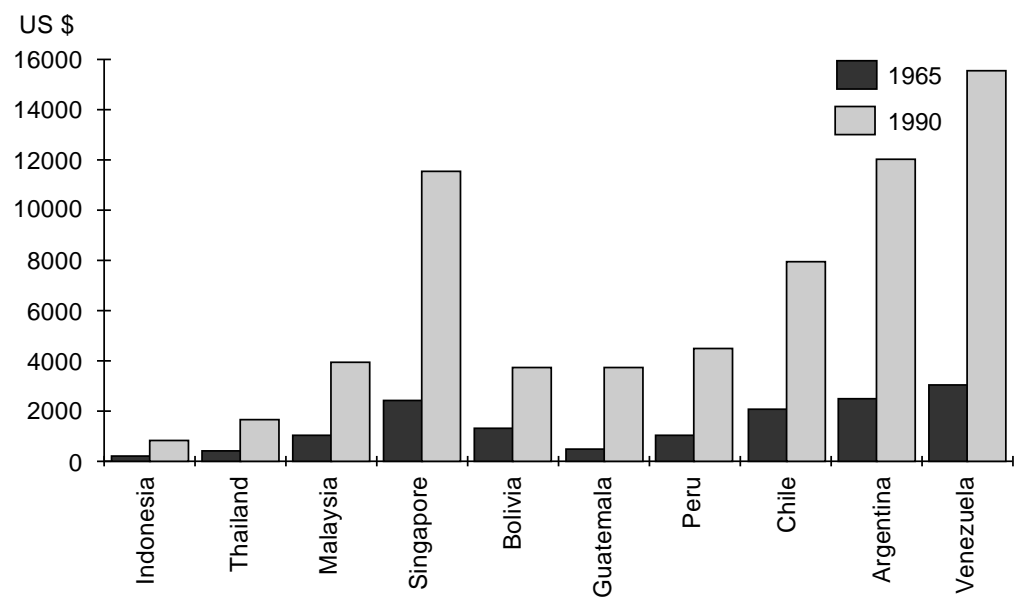

Figure 3 Hypothetical levels of per capita GNP in 1990 under the assumption of a Singapore 1965-90 growth rate 


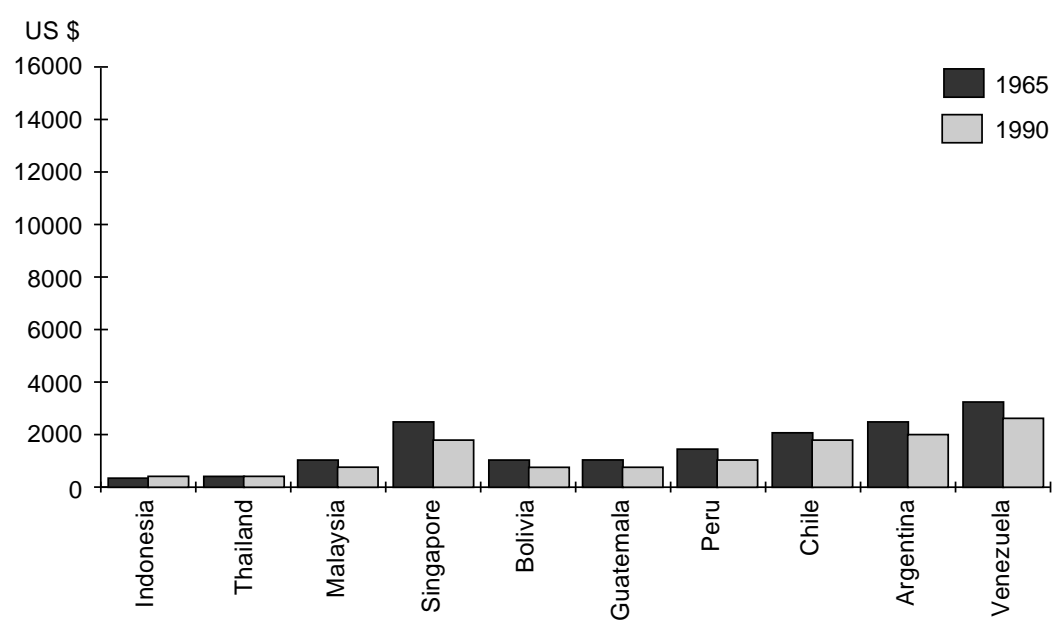

Figure 4 Hypothetical levels of per capita GNP in 1990 under the assumption of a Venezuela 1965-90 growth rate

1. The traditional growth economics, including both the old (classical and neo-classical) and new (Lucas/Romer approach) on the one hand; and

2. The political-economic and institutional approach on the other.

The first approach starts from economic determinants, mainly factors of production such as physical and human capital, labour supply and the corresponding accumulation processes of these inputs. The central controversy concerns the relative roles of accumulation on the one hand, and progress in total factor productivity - technical progress - on the other.

New growth theory is basically the attempt to endogenize these dynamic forces of productivity increase, by explicitly modelling economies of scale and/or all kinds of positive spillover effects on the supply and demand side of the growth process. The old growth accountingcum-production function analysis in the framework of time series regression for individual countries has recently been superseded by cross-country growth regressions for medium and long-term periods.

Following the lead of Barro (1991) and using the methodology of Leamer, (1983) the new empirical approach has in my view reconciled the contrasting hypotheses of Solowian (1956) and Romeronian (1990) models. Private physical and human investment in capital are both robust determinants, but so are initial conditions - if we account for the 


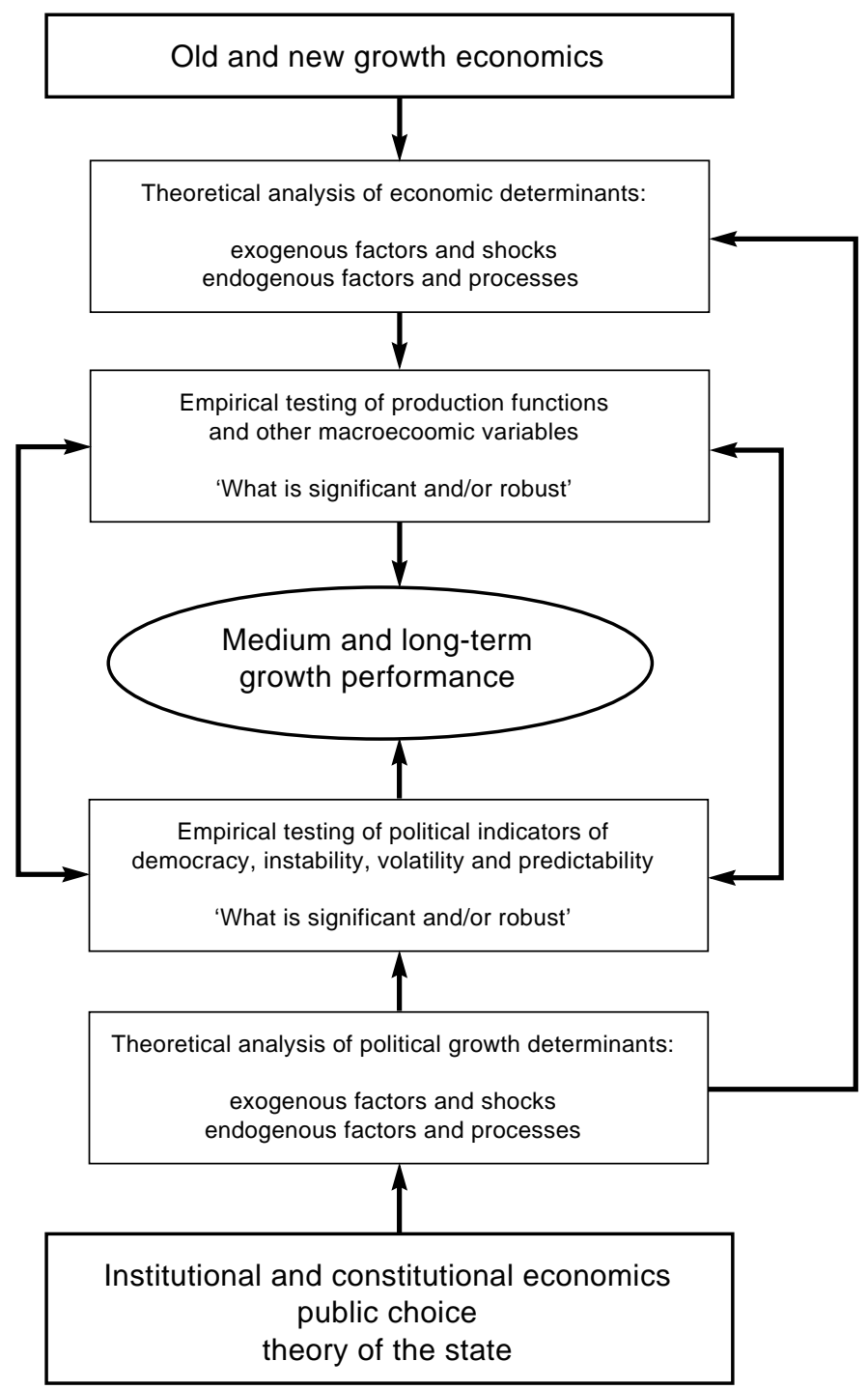

Figure 5 The two branches of growth theory 
differences in investment. This leads smoothly to the concept of conditional convergence, implying that different countries have different steady states. The fact that certain LDCs are not catching up means they are stuck in a low-level dynamic equilibrium because their steadystate parameters - mainly the rate of capital investment and progress in technology - are trapping them there.

This conditional convergence result can therefore be interpreted as an immense catching-up potential for the laggards. A poor and slowlygrowing country which overcomes some crucial obstacle that has locked it into a low-growth or no-growth steady state has formidable opportunities for rapid development - if, and only if, it can eliminate these barriers. First, we need to know why the crucial variables assumed to be exogenous in the Solow model vary so much from country to country. Next we are faced with the question of the determinants of these enormous cross-country differences (see the lowest box in Figure 5).

\section{WHY FOCUS ON INSTITUTIONAL OR POLITICAL DETERMINANTS OF GROWTH?}

Institutional and constitutional economists as well as the 'public choice' school have always suspected 'politics' to be the missing link. But why should political stability be a crucial factor in explaining a country's steady state? A strong argument can be made by reconsidering the convergence findings that show unconditional convergence within a country. In the USA, European countries and Japan, regions are converging to the same steady state - thus confirming evidence that 'being part of a country' levels out differences in economic performance across regions. Yet what characterises 'being part of a country'? Probably the most fundamental factor is being subject to the same rules of the game - in other words, having a similar political system.

The main growth factors - labour, human and real capital, and technology - are all mobile. If, for example, a country does not have the specialized technology or personnel required for its production, this can easily be imported. But what cannot be imported is the system of rules under which production and exchange take place: that is, the political system. Perhaps the most powerful demonstration of the importance of differing political systems on economic performance is the case of the USA and Mexico. For almost two centuries the USMexican border has marked the line between the world's most advanced nation and one of the poorest. This frontier has been more or 
less open to trade in goods, capital and labour, but the income differences between the two countries have not been eradicated. It is not geography, culture or the availability of factors of production that determine this border, but the political reach of the specific nation. Otherwise, it would be difficult to understand why, say, Massachusetts and Texas have similar standards of living, while the differences in economic performance between Texas and northern Mexico persist.

\section{WHERE DO WE GO FROM HERE?}

It is hard to negate the decisive role of the political dimension in economic development. But it is even harder to get an analytical handle on this factor and to test empirically for it. In contrast to the purely economic determinants in the top half of Figure 5, the number and variety of specific candidates for the 'villain in the piece' is much greater in the lower half. Furthermore, the ultimate determinants of those political factors to be significant and robust in cross-country regressions are less clear.

Some think that 'economic freedom' (property and contracting rights) is the crucial element. Some look at 'democracy' or 'authoritarianism', while others stress the volatility of the macroeconomic parameters. Our own previous work has focused more on 'predictability', or, as our group described it, the 'credibility' of the political rules for the economic game, and others point to 'violence', 'corruption' or other 'abuses of government power or bureaucratic discretion'. The measurement of these elements poses an even bigger problem. A lot of ingenuity can be admired in the vast literature on this subject, both with regard to the so-called objective indicators digested from existing statistics, or data generated by questionnaires addressed directly to experts or (as in our case) to private-sector agents.

Some of these exercises result in hit lists of countries ranked from best to worst based on specific indicators or combinations thereof. Of course, given the differences in methodologies applied, timespans covered and the indicators selected, the general picture remains rather blurred. Table 1 displays our own ranking of thirty-one LDCs and FCCs respectively based on our Credibility Index, which holds up well in regression analysis. 
Table 1 Indicator of political credibility

\begin{tabular}{|c|c|c|c|}
\hline & $1981-85$ & 1986-90 & 1981-90 \\
\hline Singapore & 1.45 & 1.25 & 1.35 \\
\hline Malaysia & 1.57 & 1.29 & 1.43 \\
\hline Thailand & 1.71 & 1.71 & 1.71 \\
\hline Senegal & 1.59 & 2.14 & 1.87 \\
\hline Indonesia & 2.10 & 2.30 & 2.20 \\
\hline Turkey & 3.50 & 2.50 & 3.00 \\
\hline Sri Lanka & 3.38 & 2.63 & 3.01 \\
\hline Chile & 3.37 & 2.97 & 3.17 \\
\hline Mozambique & 3.00 & 3.25 & 3.13 \\
\hline Estonia & na & 3.45 & na \\
\hline Ghana & 3.33 & 3.50 & 3.42 \\
\hline India & 4.00 & 3.50 & 3.75 \\
\hline Bolivia & 4.15 & 3.50 & 3.83 \\
\hline Costa Rica & 3.44 & 3.56 & 3.50 \\
\hline Peru & 4.44 & 3.64 & 4.04 \\
\hline Ecuador & 3.07 & 3.67 & 3.37 \\
\hline Rwanda & 3.33 & 3.67 & 3.50 \\
\hline Colombia & 4.21 & 3.74 & 3.98 \\
\hline Argentina & 5.12 & 3.79 & 4.46 \\
\hline Sudan & 3.40 & 4.00 & 3.70 \\
\hline Mexico & 3.67 & 4.00 & 3.84 \\
\hline Nigeria & 3.50 & 4.17 & 3.84 \\
\hline Lithuania & na & 4.21 & na \\
\hline Cameroon & 2.34 & 4.22 & 3.28 \\
\hline Panama & 3.27 & 4.33 & 3.80 \\
\hline Venezuela & 3.60 & 4.35 & 3.98 \\
\hline Brazil & 3.37 & 4.57 & 3.97 \\
\hline Latvia & na & 4.60 & na \\
\hline Guatemala & 3.87 & 4.67 & 4.27 \\
\hline Tanzania & 3.88 & 4.88 & 4.38 \\
\hline
\end{tabular}

Note: na: not available

Sources: Borner, Brunetti and Weder (1995); Borner, Kobler and Winiker (1997).

\section{WHY THIS CONFERENCE?}

At the San José Conference, we set out to examine the institutional and political dimension of economic development from different angles and perspectives. The common thread was the assumption that the state and its institutions were crucial to development: for better and for worse. The state is both a necessary political precondition for a self-propelling exchange economy, and potentially its biggest en- 
emy. The individual agent, too, benefits most by cooperating in such an exchange economy, but only if he can be sure that the other party will not defect. This again assumes transparent and systematically enforced rules of the game.

The crucial element for the solution to this dilemma is the creation of a state that uses its monopoly power to set and enforce strict and predictable rules for economic transactions. The discretion of the state in the most developed market economies is held in check by a complex network of control mechanisms that limit the power of this third party in private contracts. Although in most OECD countries today the state is constrained democratically in its discretionary power, the historical process leading to this development may have seen a government with dictatorial powers as its starting point. In other words, the 'ideal' state did not evolve as a rational response to the 'prisoner's dilemma', but was established by gradually chipping away increasing amounts of power from a dictator or sovereign. The monopoly of power that the state requires, if property rights are to be credibly enforced, introduces an inherent danger. If the state is the strongest power, a large potential exists for discretionary action by this omnipotent party. In political systems in many LDCs this tension is not resolved, leading to endemic institutional instability. Most LDCs inherited (with decolonization) authoritarian regimes and/or elitist governments that seized power by force. In other words, they began independent governance with a rudimentary state (with a low level of legitimacy) that quickly led to a set of highly discretionary power structures.

Political explanations of cross-country growth differences as well as the (historical) long-term analysis of specific countries are currently experiencing a renaissance in academic and policy-making circles. On the academic side, this renewed interest is related to the revival of growth theory and its new search for the sources of growth. Political institutions, (that is, the rules which govern economic interaction), their stability, and their enforcement are among the prime candidates for explaining differences in economic performance across countries. On the policy-making side, interest in institutional failure and success is rooted in the empirical observation that the purely economic approaches to policy reform in LDCs often fail to deliver the expected results. It is suspected that this failure can be attributed to an unfavourable institutional environment. Both the academic and the policy-making world have tackled the institutional challenge, and a number of conceptual approaches have been developed. Thus far, the different branches coexist, but are not really interconnected: governance, literature, economic 
history, political economy, new institutional and constitutional economics, public choice theory or the new growth theory - to name just a few of the different interrelated approaches.

\section{THE SAN JOSE CONFERENCE}

Leading scholars from all branches of economic and political science were united at this Conference, and engaged in a creative and productive exchange in an attempt to further an understanding of dynamic economies. In the remainder of this Introduction we offer brief summaries of the authors' contributions. In Part I, 'The State and Development', a leading political scientist and three economists discuss the scope of the problem and attempt to find answers. In Chapter 1, 'Institutions as Investments', Robert Bates takes a new look at the institutional basis for investment and growth. He shows how institutions in many societies developed as a reaction to a problem. In some of the cases he cites, the market may have provided the solution by developing a suitable business culture. However, public institutions also proved to be important. The very diversity of the examples shows the complexity of the political economy of institution building.

In Chapter 2, entitled 'Some Lessons on the Efficiency of Democracy from a Study of Dictatorship', Ronald Wintrobe first shows that the classical model of rent-seeking is much less efficient under a democracy, and is therefore wasteful because the multiple claimants to the rents are likely to lead to increasing competition. If this competition is itself wasteful, the loss to society is likely to be large. Rent-seeking is likely to be more efficient under dictatorship. Second, Wintrobe demonstrates that this conclusion disappears when two points are taken into consideration: namely, who gets the rents, and the information inefficiency of dictatorship. He illustrates this with numerous examples, but the conclusion depends crucially on the type of democracy or dictatorship, as well as the country's bureaucracy.

In Chapter 3, 'The Economics of Autocracy and Majority Rule: The Invisible Hand and the Use of Force', Mancur Olson and Martin McGuire introduce an innovative and rational concept of encompassing interest to analyse the economics of autocracy and majority rule. This idea leads to an 'invisible hand' in politics which restrains those in power from stealing (autocracy) or from redistributing 'too much'. The basic assumption is that either a dictator or a majority face incentives which restrain the discretionary actions of government. The authors formu- 
late conditions under which the interests of society are consistent with those exercising political monopoly power. This allows for a comparison between the outcomes of autocracy and different types of representative government. In spite of qualifications and limitations, Olson and McGuire present a formal model, which extends the idea of the 'invisible hand' to the realm of politics, and helps to explain why quite different political systems have enabled economic progress.

In Chapter 4, the last chapter in this section, Peter Bernholz looks at the causes of change in political-economic regimes. Why do political-economic regimes change, quite often in a fundamental and dramatic way? Bernholz explains systemic collapses through different interacting forces; namely (i) unsatisfactory economic performance; (ii) domestic political competition for power; (iii) international competition for power; and (iv) ideological or religious reorientation. The author applies his framework to a wide range of historic examples, including the ancient Greek city-states and the Soviet empire. Bernholz synthesizes his theoretical and historical analysis into the concept of a longterm cycle of political-economic regimes. Democratic free market economies degenerate either into excessive welfare and/or intervention states. The ensuing crises give rise to a new cycle and ideological movement wanting to seize power and transform the economic system. Central planning leads to dictatorship, which leads in turn to deteriorating internal economic conditions and a diminishing relative power position. Economic liberalization and political democratization may then launch a new cycle - an idea developed by Plato and Aristotle.

In recent years a large research effort has been made, often by international institutions, to analyse the effects of economic volatility. In Part II, under the heading 'Volatility, Uncertainty, Institutional Instability and Growth', we have grouped five contributors. It begins, in Chapter 5, with Michael Gavin and Ricardo Hausmann from the InterAmerican Development Bank, writing on 'Macroeconomic Volatility and Economic Development'. They focus on macroeconomic instability in general, and Latin America in particular. Their approach is primarily empirical: based on cross-country regressions comparing Latin American countries with industrial economies, the authors unearth strong and stark findings - (i) in terms of non-monetary quantities, Latin America is two to three times as volatile as the industrial nations; (ii) Latin America stands alone in the high level and high volatility of its inflation and monetary growth; and (iii) macroeconomic volatility is negatively associated with long-term economic growth. The cost of volatility is about one percentage point of the annual growth rate. Volatility, in 
this sense, originates either from external shocks or - and this is the more relevant - from institutional and/or political sources: Gavin and Hausmann further demonstrate that direct measures of political instability, as well as monetary volatility and exchange rate regimes, matter most. The results give rise to some optimism concerning the effectiveness of institutional reform. The Gavin and Hausmann study is indeed a far cry from the old Latin American lament about overpowering external shocks.

In Chapter 6, 'Political Variables in Growth Regressions' by Aymo Brunetti, the author summarises the explanatory power of the most commonly used political variables in a comparative empirical study of cross-country regressions. He considers five categories of political variable: measures of democracy, political instability, policy volatility; political measures based on experts' opinions; and survey data. $\mathrm{He}$ finds that the frequently used measures of democracy and political instability are only weakly related to cross-country differences in economic growth. On the other hand, indicators of policy volatility and survey measures of perceived reliability of the political framework seem more promising as potential determinants of economic growth.

Many Latin American countries have shared the frustrating experience of implementing far-reaching macroeconomic reform without any obvious impact on economic growth. Philip Keefer and Stephen Knack argue in Chapter 7, entitled 'Political Stability and Economic Stagnation', that macroeconomic stability alone is not sufficient for catching up, but that the establishment of institutions to protect property and contractual rights is at least as important. This approach follows Douglass North's analysis, which declares the inability of LDCs to develop effective low-cost enforcement of contracts is the most important source of under-development. Using their data set on the security of contractual and property rights, the authors show that Latin American countries have less favourable institutions than OECD countries and the East Asian economies. The same data are then used in growth regressions to show that both indicators are significantly related to cross-country differences in economic growth.

In Chapter 8, 'Political Uncertainty, the Formation of New Activities and Growth', Joshua Aizenman explores the strong negative link between many types of economic and political variability and investment. In the first part he discusses risk aversion. The concept chosen for further analysis is disappointment aversion, which is modelled in a tractable way. Next, he explores its effect, by combining it with a Romertype growth model, showing the effects on investment of variable taxes, 
and (more loosely) other forms of tax. This Section closes with Chapter 9, entitled 'Does Economic Growth Lead to Political Stability?' by Martin Paldam. Here, Paldam uses a more systematic approach than in much of the earlier literature. He examines whether political transition could be a part of the economic one, and finds that economic growth appears to be a weak cause of political instability. He also finds that the 'vote and popularity function' literature shows that governments become more popular and stable if they are perceived to generate more growth, but also that any popularity gain is shortlived. Finally, the literature on the strike function shows that higher growth generates more conflict. He concludes that the evidence adds up to an unclear picture.

Institutions often fail to perform as designed. Frequently, the reasons are associated with forms of corruption. This is the subject of the two chapters in Part III, headed 'Rent-Seeking and Corruption'. In Chapter 10, John Mukum Mbaku discusses the relationship between these phenomena, and in his review of the literature, concentrating on studies of LDCs with particular reference to Africa, shows that the best understanding of the phenomenon of corruption is obtained by taking a 'public choice' approach. He ends by discussing proposals for reform. The second chapter in this section, Chapter 11, is 'Corruption and Countervailing Actions in Pakistan' by M. Shahid Alam, who attempts to learn about corruption by examining Pakistani newspapers. Systematic reading of three newspapers over two months yielded a data set of 329 reported cases of corruption, which provided an empirical foundation for this study. He finds that most cases can be classified as either coercive or collusive, and shows that the losers from corruption - especially coercive corruption - often resort to countervailing action.

Part IV we have called 'Case Studies: Policies, Countries and International Organizations'. The first chapter (Chapter 12), by Rudiger Dornbusch, 'Disinflation and Overvaluation', focuses on currency crises, and draws on the experience of Chile, Mexico and Brazil. The author shows that recurrent monetary breakdowns are not accidental, but are the final stage in a political-economic chain. The initial stage is usually one lacking macroeconomic equilibrium. The easiest option seems to be to aim for high output, high real wages and to finance the external deficit from increased debt. Although disequilibrium may be postponed, vulnerability is increased. The inflation-depreciation linkage provides the other ingredient leading to currency collapse. Exchangerate manipulation may seem to offer a cost-free route to disinflation, but will in time invite the next currency crash. Dornbusch applies his 
analytical framework to an examination of Chile in the late 1970s, and Mexico and Brazil in the 1990s. He notes that a misreading of the circumstances by governments, and their subsequent actions, will eventually lead the international financial markets to force an adjustment, which will lead to the start of a new cycle.

Vittorio Corbo's chapter (Chapter 13), 'Government Policy, Saving and Growth in Latin America', explores the complex relationship between saving, growth and economic policy. With the emergence of a new growth theory, the positive association between 'good policy' and economic growth factor accumulation is seen as only a part of the growth process. Correct economic policies will ensure a higher level of investment in both human and physical capital, which will lead to higher long-term growth, but this is dependent on an increase in national saving rates. This finding was confirmed by an examination of Latin American data. Corbo ends by considering Chile's recent economic success. He argues that the increase in the savings rate was first achieved by an increase in the government's rate of saving, while institutional developments created an environment that encouraged private savings. These actions promoted a virtuous cycle. The development of a robust capital market was helped by reforming the pension system and the introduction of a Copper Stabilization Fund.

In Chapter 14, 'Growth and Political Violence in Northern Ireland, 1920-96', Vani Borooah takes a close look at the impact on the economy of transfer flows from Whitehall to Northern Ireland and the distortions these cause. He considers the effects that peace might have on the economy and discusses ways of generating sufficient economic growth to absorb change.

The last two chapters in this section are concerned with aid donors and technical cooperation. Tony Killick, in Chapter 15 - 'Donor Conditionality and Policy Reform' - discusses the conditions increasingly attached by donors to their loans to LDCs. These conditions, which are intended to promote good governance and economic policies, are rarely fully implemented and yet this does not stop loan disbursement or the granting of new loans. Killick argues his case using World Bank data from structural adjustment loans. Chapter 16, 'Institutional Analysis of Technical Cooperation' by Dieter Kattermann, reviews the debate on development policies and activities, particularly institutional building, capacity building and governance. Kattermann discusses the growing critique of the existing forms of technical cooperation and how the focus on institutional development and capacity building has prompted new approaches to institutional analysis in 
international organizations. He argues that greater credibility and sustainability of comprehensive economic reform programmes might be achieved from a combination of academic research on institutions, improved institutional development and capacity building initiatives, and urges development practitioners and researchers to combine forces.

Part V we have called 'Constitutional and Administrative Reform'. It is often alleged that economists discuss problems, but are too timid in proposing solutions, particularly where far-reaching solutions appear to be required. However, we include three chapters here that do not shy away from proposing sweeping reforms. Chapter 17, by Bruno S. Frey, entitled 'Developing Democracy in Developing Countries', gives a general recipe for constitutional reform. He suggests reorganizing the political decision process into overlapping decision areas he terms FOCJ, each being the optimal area for a certain type of decision. Depending on the number of FOCJ required, this could entail either minor or major reform. Next, in Chapter 18 (Ethnic Rent-Seeking, Stability and Institutional Reform in Sub-Saharan Africa), Mwangi S. Kimenyi discusses the need for radical constitutional reform in Africa. His analysis concludes that tribalism cannot be eradicated, but should be at the root of constitutional reorganization. He outlines how this could be achieved with some constitutional recommendations. Finally, Robert Keitgaard, in Chapter 19, entitled 'Healing Sick Institutions', suggests remedies for institutions that have degenerated into lethargic inefficiency. The description of the sickness includes a collapse of incentives, including salaries, without any corresponding reduction in employment but increasing absenteeism. He discusses a number of examples and what action might be taken to revitalize these institutions, notably slimming employment and increasing incentives, particularly salaries.

Part VI concludes this volume with brief comments from three invited observers, with very different backgrounds, specially asked to comment on the papers and discussion, and offer their thoughts on the issues raised.

\section{References}

Barro, R. (1991) 'Economic Growth in a Cross Section of Countries', Quarterly Journal of Economics, vol. 106, pp. 407-43.

Barro, R. and Sala-i-Martin, X. (1991) 'Convergence across States and Regions', Brookings Papers on Economic Activity, no. 1, pp. 107-82.

Borner, S., Brunetti, A., and Weder, B. (1995) Political Credibility and Economic Development (London: Macmillan). 
Borner, S., Kobler, M., and Winiker, C., (1997) 'A Political Credibility Indicator for LDCs and Baltic States', Baltic Journal of Economics.

Brunetti, A. and Weder, B. (1994) 'Political Credibility and Economic Growth in Less Developed Countries', Constitutional Political Economy, pp. 23-43.

Leamer, E. (1983) 'Let's Take the Con out of Econometrics', American Economic Review, vol. 73, pp. 31-43.

Levine, R. and Renelt, D. (1992) 'A Sensitivity Analysis of Cross Country Growth Regressions', American Economic Review, vol. 82, pp. 942-63.

Romer, P. (1990) 'Endogenous Technological Change', Journal of Political Economy, vol. 98, pp. 71-102.

Solow, R. (1956) 'A Contribution to the Theory of Economic Growth', Quarterly Journal of Economics, vol. 70, pp. 65-94. 